\title{
Reducing Healthcare Costs Requires Good Market Design
}

\author{
PETER CRAMTON AND BRETT E. KATZMAN
}

A

s the Government comes to grips with rising deficits, there is a bigger economic tsunami lurking in the background-many tens of trillions in unfunded Medicare costs. Innovations are desperately needed to contain healthcare costs and avoid fiscal disaster. One thing in need of change is Medicare's pricing of equipment and supplies using 25-year-old rate schedules adjusted for inflation and periodically cut. Everyone agrees that this outdated administered pricing system makes little sense.

The solution is to establish prices in competitive markets, and happily, Congress has

Peter Cramton is Professor of Economics at the University of Maryland and an expert on market design. Brett E. Katzman is Professor of Economics at Kennesaw State University; his research on Medicare auctions won the Southern Economics Association's best paper award in 2008.

(c) The Berkeley Electronic Press been pushing for certain Medicare supply prices to be set in competitive auctions. The problem is that even though this pushing began in the 1997 Balanced Budget Act, after 13 years Medicare's proposed auctions are a scandal and will result in an unsustainable system, loss of quality and selective provision of supplies to Medicare beneficiaries. The problems are predictable in theory and the pilot runs thus far prove as much.

Pilot auctions began in two cities in 1999 and 2002. These had serious problems, which led the Centers for Medicare and Medicaid Services (CMS) to make minor changes before initiating the latest competitive bidding program in nine cities in 2008. Congress cancelled the 2008 auctions due to complaints about unfair qualification procedures and unsustainably low prices. After further minor changes, the 2008 auctions were rebid in November 2009. However, the auctions continue to have fatal flaws.

On September 20, 2010, we presented our case by email with supporting materials to over two-hundred experts, asking them to be signatories to a letter to Health Subcommittee Chairman Stark making the points expressed here. $^{2}$ The result was overwhelming: a group of 167 experts signed the letter within our 48hour deadline. Only 22 declined to sign, and in each case, responded that the reason for not signing was insufficient time to fully review the letter and other materials. Chairman Stark responded within two days with a letter to the head of CMS concluding, "I urge you to give these comments and recommendations serious consideration. I would also request that you inform me in a timely way as to whether CMS plans to incorporate any of the recommended 
changes and if not, why not." The ball is now in CMS's court.

\section{THE PROBLEMS}

So what are the problems with the current design? The overall problems are four. The first three combine to assure that the auction prices are severely distorted from competitive market prices. The fourth, a lack of transparency, prevents the pricing problems from being quickly identified and corrected. The result is wrong prices. Some are too high, causing excess expense. Others are too low, causing supply shortages and compromising service quality. These problems will directly affect seniors and are completely unnecessary.

Bids Are Not Binding Commitments

Tn the Medicare auction bidders are not bound by their bids. Any auction winner can decline to sign a supply contract following the auction. This undermines the credibility of bids and encourages low-ball bids in which the supplier acquires at no cost the option to sign a supply contract. This aspect of the proposed system has led to the predictable outcome where a number of bidders, realizing that prices were set below their costs, have refused to sign contracts in the pilot programs.

Flawed Median-Bid Pricing Rule

$\triangle \mathrm{s}$ in standard procurement auctions, bids - 1 are sorted from lowest to highest, and winners are selected, lowest bid first, until the cumulative supply quantity equals the estimated demand. The odd part comes next. The proposed system sets reimbursement prices at the median of the winning bids, rather than the clearing price, where supply and demand balance. Thus, fifty-percent of the winners are offered a contract price less than their bids.

Since most providers are small, they lack the resources to invest in information and strategy in preparing bids. For them an effective and easy strategy is the low-ball bid. It is a winning bid with a negligible effect on the price. However, with many firms following this strategy the median-bid price is significantly biased downward and possibly below the cost of all suppliers. This possibility is not a problem for the low-ball bidders since, as described above, suppliers have the option of not signing the contract in such an event. The implication is that many prices may be below everyone's costs and therefore be unsustainable. Not good. Again, this may lead to supply disruptions and shortages, eroding access and quality for beneficiaries and discouraging the development of improved technologies.

Encourages Strategic Bid Skewing

The current system selects winners using

I composite bids, which are an average of a bidder's bids across many products, weighted by government demand estimates. This provides a strong incentive for bidders to distort bids away from costs-the problem of bid skewing. Bidders submit low bids on products for which the government has overestimated demand and high bids on products where the government has underestimated demand. As a result, prices for individual products do not align with costs.

Bid skewing is a common problem in U.S. timber auctions. There it leads to higher cost uncertainty. Its impact in the Medicare auctions and beneficiaries will be much more severe-selective fulfillment of customer orders. Medicare beneficiaries are likely to find that only high-margin products are available. 
Lack of Transparency

T $\mathrm{n}$ the Medicare auctions, it is unclear how 1 demand and bidder capacities are determined, which are the two main inputs other than price bids used to determine the winners and the product prices. In addition, both quality standards and performance obligations are unclear. Remarkably, bids from the latest test of the design, covering nine cities, were taken in November 2009 and now more than ten months later we still do not know which firms were awarded contracts. This lack of transparency is unacceptable in a government auction, leads to fraud and collusion, and is in sharp contrast to well-run government auctions such as the Federal Communications Commission spectrum auctions.

These four fundamental problems suggest that the likely long-run outcome will be a "race to the bottom," in which providers become increasingly unreliable, product and service quality declines, and fraud and abuse increases.

\section{KEY FEATURES OF A GOOD AUCTION DESIGN}

ompetitive bidding techniques have improved dramatically over the last decade. Complex auctions like the Medicare program can be designed to achieve the objectives of low cost and high quality with little implementation risk. The appropriate bidding mechanism would arise from a collaboration of government officials, industry representatives, and auction experts. It would emphasize transparency, good price and assignment discovery, and strategic simplicity. The result would be sustainable long-term competition among suppliers that reduces costs while maintaining high quality.

\section{CONCLUSION}

The switch to market pricing is not easy for a 1 government agency. Medicare's experience with medical supplies illustrates the challenges and offers important lessons. The key lesson is that, although market methods hold much promise, the government must collaborate with both expert market designers and industry to maximize the benefits of market methods. The government would never consider building a bridge without input from bridge experts; likewise, it should not attempt to build markets without input from experts in market design.

The Medicare competitive bidding program demonstrates what can happen without expert advice. The Medicare auction creates the wrong incentives for bidders. The end result is prices that differ dramatically from competitive market prices. Continued roll-out of the current design will result in government failure, both as a result of the decline in service quality and selective provision of supplies to Medicare beneficiaries.

Such a failure is not necessary. The government should develop a new system based on our accumulated stock of knowledge about the design of complex auction markets.

Using competitive bidding to price Medicare supplies is a sound idea, but only if it is done right.

Letters commenting on this piece or others may be submitted at http://www.bepress.com/cgi/ submit.cgi? context=ev.

NOTES

1. Alan Auerbach and William Gale discuss the size of unfunded medicare costs. Available at: http://www. brookings.edu/papers/2010/0917 federal budget outlook auerbach gale.aspx.

2. See Peter Cramton's "Email to Auction Experts on the Medicare Competitive Bidding Program, " Available at: http://goo.gl/Q1JR.

The Economists' Voice www.bepress.com/ev October, 2010 


\section{REFERENCES AND FURTHER READING}

Auerbach, Alan J. and William G. Gale (2010)

"The Federal Budget Outlook, Chapter 11," Working Paper, Brookings Institution, September 15. Available at: http://www.brookings.edu/ papers/2010/0917 federal budget outlook auerbach gale.aspx.

Cramton, Peter (2010) "Email to Auction Experts on the Medicare Competitive Bidding Program," September 20. Available at: http://goo.gl/ Q1JR.

Cramton, Peter, Yoav Shoham, and Richard Steinberg (2006) Combinatorial Auctions. Cambridge, MA: MIT Press.

Federal Register (2007) "Medicare Program; Competitive Acquisition for Certain Durable Medical Equipment, Prosthetics, Orthotics, and Supplies (DMEPOS) and Other Issues; Final Rule," 72(68):18041-18047. Available at: http:// goo.gl/bYCO

"Letter from 167 Concerned Auction Experts on Medicare Competitive Bidding Program" to Chairman Stark, Health Subcommittee, Ways and Means, U.S. House of Representatives, September 26, 2010. Available at: http://goo.gl/ h6yq.
McGeary, Kerry Anne and Brett Katzman (2008) "Will Competitive Bidding Decrease Medicare Prices?" Southern Economic Journal, 74:839-856. Available at: http://ssrn.com/abstract $=628721$.

"Letter from Chairman Stark," Health Subcommittee, Ways and Means, U.S. House of Representatives, to Administrator Donald Berwick, Centers for Medicare and Medicaid Services, September 28, 2010. Available at: http://goo.gl/ KWOO.

Milgrom, Paul (2004) Putting Auction Theory to Work. Cambridge, England: Cambridge University Press.

Rettenmaier, Andrew J. and Thomas R. Saving (2010) "The Elephant in the Room: Coping with the Long-Term Problem of Medicare Costs," The Economists' Voice, 6(5): Art. 1. Available at: http://www.bepress.com/ev/vol6/iss5/artl. 